UDC 616-018.1"712.4":57.088

\title{
Distribution of transplanted human mesenchymal stem cells from Wharton's Jelly in the central nervous systems of the EAE rats
}

\author{
M. V. Kovalchuk ${ }^{1,2}$, O. G. Deryabina' 2 L. D. Pichkur ${ }^{3}$, S. A. Verbovskaya ${ }^{3}$, \\ N. S. Shuvalova ${ }^{2}$, O. L.Pichkur, ${ }^{3}$ V. A. Kordium ${ }^{1}$ \\ ${ }^{1}$ Institute of Molecular Biology and Genetics, NAS of Ukraine \\ 150, Akademika Zabolotnoho Str., Kyiv, Ukraine, 03680 \\ ${ }^{2}$ State Institute of Genetic and Regenerative Medicine, NAMS of Ukraine \\ 67, Vyshhorodska Str., Kyiv, Ukraine, 04114 \\ ${ }^{3}$ Institute of Neurosurgery named after A. P. Romodanov, NAMS of Ukraine \\ 32, Platon Mayboroda Str., Kyiv, Ukraine, 04050 \\ kovalchukmar@gmail.com
}

\begin{abstract}
Human Wharton's Jelly MSCs (hWJ-MSCs) have a considerable advantage and potential in treating the central nervous system diseases and can be a new alternative treatment of Multiple Sclerosis (MS). Aim. To study the persistence and distribution of hWJ-MSCs along the neuraxis following transplantation in central nervous system of rats with experimental autoimmune encephalomyelitis (EAE), the animal model of MS. Methods. Isolation and cultivation of hWJ-MSCs in vitro. Immunological phenotyping by flow cytometry. EAE induction. Intrathecal (suboccipital) injection of MSCs into CNS of SCH-induced EAE rats. Persistence of hWJMSCs in the CNS of hWJ-MSCs -treated rats was detected through detection of the human alpha-satellite DNA in the tissue sections and the cerebrospinal fluid (CSF) by PCR at days 2, 3, 4 and 5. Results. PCR-assays for alpha-satellite sequences revealed that human DNA was detected during 5 days following intrathecal injection at the peak of disease in the treated rats. It has been demonstrated that the human DNA was traced in CSF and various segments of a spinal cord. Conclusions. The data obtained suggest that intrathecally delivered hWJ-MSCs, with time, can migrate through the CSF from the injection site to various segments of CNS and persist therein during the first week of post transplantation, which was performed at the EAE disease peak in the xenogeneic setting without immunosuppression. hWJ-MSCs may be considered as a delivery cell source of therapeutic molecules for CNS inflammatory diseases.
\end{abstract}

Key w or d s: hWJ-MSCs, experimental autoimmune encephalomyelitis, alpha-satellite DNA.

\section{Introduction}

To date Multiple Sclerosis (MS) is considered as a complex and chronic immune-mediated and neurodegenerative disease caused by genetic susceptibility and environmental risk factors $[1,2]$. It is characterized by infiltration of immune cells from the bloodstream into the central nervous system (CNS) and damage of myelin and axons. Over the last years, the approaches for MS treating have been developed to suppress the immune system for controlling the inflammatory process with the aim of the disease progression termination. The currently used treatments are only partially effective [3-5]. New cellbased therapies are needed for neurogenesis or myelogenesis of the damaged CSN tissues and recovering the neurological functions $[6,3]$.

Multiple studies have demonstrated that mesenchymal stem cells (MSCs) of different origin are able to ameliorate experimental autoimmune encephalo-

(C) 2015 M. V. Kovalchuk et al.; Published by the Institute of Molecular Biology and Genetics, NAS of Ukraine on behalf of Biopolymers and Cell. This is an Open Access article distributed under the terms of the Creative Commons Attribution License (http://creativecommons.org/licenses/by/4.0/), which permits unrestricted reuse, distribution, and reproduction in any medium, provided the original work is properly cited 
myelitis (EAE), an animal model of MS [5, 7-9]. The cells have displayed immunomodulatory, anti-inflammatory, pro-regenerative, neuroprotective, and angiogenic properties in the models of a number of neurological disorders [10-12] including significant reduction of spinal cord inflammation and reduced demyelination and axonal loss in the EAE lesions [7]. Also, in the mouse EAE model, the administration of MSCs exhibited dose-dependent protection from EAE induction, and in an established EAE it reduced the disease progression and severity [7].

It is shown that MSCs can migrate locally into the damaged CNS areas where they have the potential to support local neurogenesis or myelogenesis through the neurotrophic effects, stimulation of resident CNS stem cells, induction of in situ immunomodulation, or, theoretically, even transdifferentiation [5]. It has also been reported that MSCs could function as neurotrophic sources via the cerebrospinal fluid (CSF) [13]. Isakova et al. found that human MSCs transplanted in brain were dynamically distributed and preferentially localized in specific anatomical regions [14], and that this process was likely mediated by the neural adhesion molecules and the guidance receptors expressed by the transplanted MSCs [15].

The mechanisms of MSC therapy and the novel therapeutic strategies for neurological treatments are being intensely investigated. The result of the cellbased therapy depends on many factors, for instance, on the choice of the cell type, route of administration, amount of transplanted cells, time window.

MSCs from the human umbilical cord Wharton's jelly might be effective in the treatment of the central nervous system diseases. An immunomodulatory effect of WJ-MSCs was evaluated in vitro and in the animal models $[16,17]$. For a long time it was thought that CNS is an immune-privileged site due to its structural features. Nevertheless, the current evidences support the idea that CNS is monitored by the immune system through a modified surveillance circuit and the concept of CNS immune privilege should be revised [18]. MS is an example of such CNS immune surveillance. The survival and distribution of hWJ-MSCs in CNS under the EAE patho- logical conditions have not been studied particularly since these factors may have a significant impact on the efficiency of cell therapy. In this context, our aim was to evaluate the hWJ-MSC persistence and posttransplantation distribution within the affected CNS of the immunocompetent EAE-model animals treated with the cells at the peak of clinical symptoms without an appropriate immune suppression.

\section{Materials and Methods}

\section{Laboratory animals}

Wistar rats (males, weight 180-200 g) were used as experimental animals. The animals were housed under standard conditions with free access to water and food. All animal experiments were done under exacting adherence with the low of Ukraine №3447IV from 21.02.2006 "The protection of animals from cruel behavior" [19] and Guide for the Care and Use of laboratory Animals [20].

\section{Cell isolation and cultivation}

Human MSCs were elaborated from umbilical cord as described previously [21]. The cells at second passage were harvested and resuspended in phosphate buffered saline (PBS), $10 \times 10^{6}$ cells per milliliter. A sample of the cells to be injected was assessed with BD FACSAria cell sorter (Becton Dickinson Biosciences, San Jose, CA, USA) and analyzed using BD FACSDiva software (v 6.1.2) to confirm proper surface marker expression (CD73, CD90, CD105 and CD34) [22].

\section{EAE induction and $h W J-M S C$ injections}

To induce EAE, rats were immunized with inoculums containing a rat spinal cord homogenized $(\mathrm{SCH})$ in PBS and emulsified at a ratio of 1:1.6 with Freund's complete adjuvant (Sigma-Aldrich) by the subcutaneous injection into hind limb footpads [23]. The EAE rats were evaluated according to the grading system for clinical assessment of EAE [24]. hWJ-MSCs were transplanted intrathecally into the animals through the cisterna magna according to the protocols for suboccipital injection. Shortly, anesthetized animals were 
fixed, the occipital protuberance at the start of the cervical spine was identified for a needle positioning towards the foramen magnum. A needle was carefully inserted through the skin until the atlantooccipital membrane was punctured. The subdural space position was verified by the return of CSF. hWJ-MSCs $\left(1 \times 10^{6}\right)$ in $100 \mu \mathrm{L}$ PBS were slowly injected to the cisterna magna on day 16 after SCH immunization. The animals that did not receive hWJ-MSCs served as a control. The rats were sacrificed for a post-morten analysis at 2, 3, 4 and $5^{\text {th }}$ days after cell transplantation (approximately 2-3 rats/group/timepoint).

\section{Isolation of DNA}

Genomic DNA was extracted from the cells of CSF using the salting out method [25] and from the brain and the spinal cord tissues using the method of Bruijn et al. [26]. The DNA obtained from untreated rat was used as a negative control and DNA from hWJ-MSCs was used as a positive control. The DNA concentration and purity were determined by optical density using the Thermo Scientific Nanodrop 2000 UV Vis spectrophotometer.

\section{Polymerase chain reaction}

The standardised PCR was performed according to Becker et al. [27]. All assays were performed in duplicate. Each reaction contained the same amount of genomic DNA template. The products were visualized by electrophoresis in $1.2 \%$ agarose gel. The following PCR primers that target a sequence in the alpha-satellite region of the human chromosome 17 were used:

5 -TGCGCGTGAAGGTTTGCCAGTGT- 3 and

5_-GCCCCCAGTCGTTCAGGTAATCATAGTCC-3 [28].

\section{Results and Discussion}

After isolation from Wharton's jelly, the cultured hWJ-MSCs were harvested at the second passage. In accordance to FACS analysis more than $90 \%$ of hWJMSCs were positive for CD73, CD90, and CD105 antigens and negative for CD34 antigen $(<2 \%)$. The cells were checked for viability via Trypan blue exclusion, counted using hemocytometer and prepared for transplantation in phosphate buffered saline (PBS) at a concentration of $10 \times 10^{6} / \mathrm{mL}$.

The rats were inoculated according to the immunization protocol, evaluated daily for signs of the disease and graded on the scale of 0 to 5 according to the severity of the symptoms [24]. It was found that immunization resulted in relapsing-remitting disease where the rats could have to 3 bouts within the experimental period. The animals with mean EAE score $=2$ (total of 46 animals) were selected for the MSC treatment.

It is known, that the route chosen for delivery of cells may influence the survival, migration and final localisation of the transplanted cells. To avoid the system effect under $i$. $v$. route of MSC transplantation and excessive incorporation of the hWJ-MSCs into other organs and systems we injected the cells into the CNS of EAE-animals.

It has been demonstrated that upon the transplantation into CNS, the cells may circulate with the flow of the cerebrospinal fluid and reach the affected CNS areas [5]. To follow the fate and the distribution of the hWJ-MSCs throughout the neuraxis of animals, four tissue CNS sections (cerebral hemispheres, brainstem within the region of injection, spinal cord from thoracic and lumbar regions) and CSF were overtime collected for isolation of genomic DNA at each time point $\left(2^{\text {nd }}, 3^{\text {rd }}, 4^{\text {th }}\right.$ and $5^{\text {th }}$ days post transplantation). The volume of CSF collected by direct cisterna magna puncture was nearly $100 \mu$ l. The cerebral hemispheres, brainstem, and spinal cord were taken out and successive sections of them were sliced. To identify human cells, we used PCR assay for human-specific alpha-satellite sequence for confirmation [28]. To facilitate the PCR-assay the same amounts of DNA were used for every reaction. The sensitivity of the assay was about 1 human cell per $10^{5}$ murine cells, as proved by logarithmic dilution steps of hMSCs in rat splenocytes. The assays for human alpha-satellite sequences indicated that the human DNA was detected throughout the study period (5 days) following the injection without an appropriate immune suppression. Table 1 provides a summarized picture of the PCR-assays. 
Table 1. hWJ-MSC detection by alpha-satellite DNA PCR

\begin{tabular}{|l|c|c|c|c|}
\hline \multicolumn{1}{|c|}{$\begin{array}{c}\text { Point transplantation } \\
\text { time }\end{array}$} & $\begin{array}{c}2 \text { days } \\
\mathrm{n}=2\end{array}$ & $\begin{array}{c}3 \text { days } \\
\mathrm{n}=2\end{array}$ & $\begin{array}{c}4 \text { days } \\
\mathrm{n}=2\end{array}$ & $\begin{array}{c}5 \text { days } \\
\mathrm{n}=2\end{array}$ \\
\hline $\begin{array}{l}\text { Cerebral hemispheres } \\
\text { Brainstem within the } \\
\text { region of injection }\end{array}$ & 1 & 0 & 0 & 0 \\
$\begin{array}{l}\text { CSF (cerebrospinal } \\
\text { fluid) }\end{array}$ & 2 & 2 & 1 & 1 \\
$\begin{array}{l}\text { Spinal cord from } \\
\text { thoracic region } \\
\text { Spinal cord from }\end{array}$ & 2 & 2 & 2 & 2 \\
lumbar region & 0 & 0 & 0 & 0 \\
\hline
\end{tabular}

PCR-positive rats at each post-transplantation time point are shown.

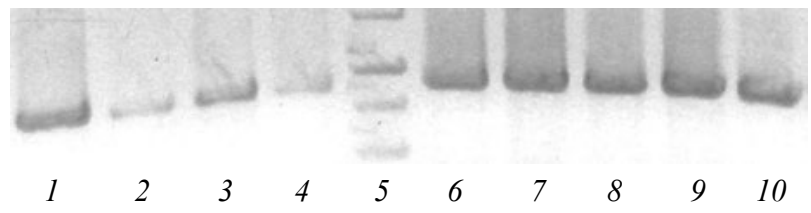

Fig. 1. The results of PCR for the presence of alpha-human DNA samples from brainstem of rats within the region of injection after administration of hWJ-MSCs at different post-transplantation time intervals. $1-2$ days; $2-2$ days; $3-3$ days; $4-$ 3 days; 5 - molecular weight marker, 1 kb DNA Ladder (Fermentas); $6-4$ days; $7-4$ days; $8-5$ days; $9-5$ days; $10-$ human MSC DNA (positive control)

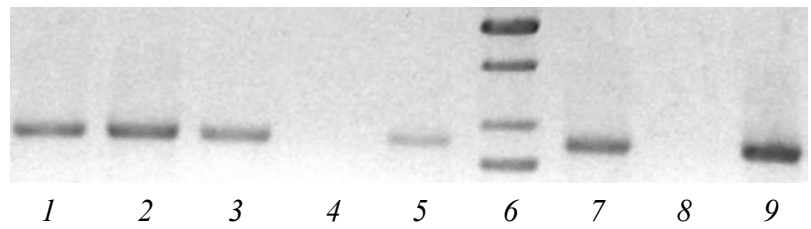

Fig. 2. The results of PCR for the presence of alpha-human DNA samples from CSF of rats after administration of $\mathrm{hWJ}$ MSCs at different time intervals of post-transplantation. 1 2 days; $2-3$ days; $3-3$ days; $4-4$ days; $5-4$ days; $6-$ molecular weight marker, $1 \mathrm{~kb}$ DNA Ladder (Fermentas); 7 - 5 days; 8 - 5 days; 9 - human MSC DNA (positive control)

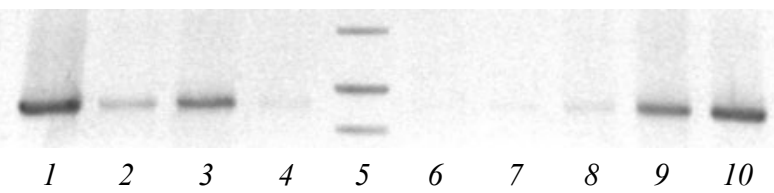

Fig. 3. The results of PCR for the presence of alpha-human DNA samples from thoracic region of rat spinal cord after administration of hWJ-MSCs at different time intervals of posttransplantation. $1-2$ days; $2-2$ days; $3-3$ days; $4-3$ days; 5 - molecular weight marker, 1 kb DNA Ladder (Fermentas); $6-4$ days; $7-4$ days; $8-5$ days; $9-5$ days; $10-$ human MSC DNA (positive control)
As to an anatomical location, it has been demonstrated that the transplanted hWJ-MSCs can migrate through CSF. The representative examples of molecular detection of hWJ-MSCs in various segments of the spinal cord, CSF, brainstem, and cerebral hemispheres are presented in Fig. 1-5. As shown in Fig. 1, all tissue samples of brainstem within the region of injection were positive for the human DNA. Probably, the majority of hWJ MSCs are initially trapped in this region and persisted there throughout all study period.

The human DNA was also detected in CSF from cisterna magna in the majority of samples (Fig. 2).

It is known, that intrathecal route for the cell delivery in neurological disease such as MS characterized by zones of tissue damage localised along the neuraxis, may promote migration of the injected cells to the proximity of the CNS lesions. Figure 3 illustrates that hWJ-MSCs may penetrate the neighbouring thoracic region of spinal cord.

Oppositely, Figures 4 and 5 demonstrate that alpha-satellite sequences were not detected in cerebral and lumbar regions of spinal cord with the exception of a single case. Possibly, major portion of the cells died during the first day after transplantation due to hypoxia and serum deprivation following transplantation and the cell amount was insufficient to induce positive PCR signal. The second variant, the cells did not penetrate to these regions. Another possible explanation is a small number of animals in each group. It is possible that with increased amount of rats the results may be different.

As some MS lesions remyelinate spontaneously and unpredictably, the timing of MSCs administration is very important but difficult to be determined. In the clinical setting, the cell-based treatment is usually applied only when MS is in progress. In this respect, despite the efficiency of preventive MS treatment with MSCs in animal models, it is of therapeutic importance that MSCs were also effective when administered to animals with established disease. Therefore we studied the retention and distribution of the intrathecally injected hWJ-MSCs in the EAE rats at delayed cell administration. 
Generally, these data have shown that human WJMSCs injected into the EAE rats at the peak of disease were allocated to the specific regions within the CNS of treated animals. During one week they were widely distributed along the neuraxis. Possibly, these cells can penetrate into the inflamed spinal cord and persist there for some time in the xenogeneic setting without immunesuppression. In contrast to these results, dissimilar survival features of the same hWJMSCs have been revealed in another rat model (experimental osteoarthritis) after injecting the cells into a knee joint, where human DNA was detected only at the first day after the injection [29]. The results obtained in the present study are in line with the earlier reports $[7,14]$.

It should be noted that PCR detection of the human-specific DNA sequences in the animal model does not give direct confirmation of the cell viability. Nevertheless, there is a close correlation between the cell viability and the possibility to detect a specific DNA sequence by PCR [30]. Comprehensive approaches are required for a direct confirmation of the cell presence and the cell viability following the transplantation. Most likely, the therapeutic effect of MSCs could be enhanced by extending their persistence after the transplantation. There is relatively large amount of studies that assess a fate of the transplanted cells in the models of a number of neurological disorders. However, a direct comparison of the experimental results is difficult due to the differences in the cell source, passages, delivery route, cell dose, recipient species, cell labelling and detecting method, environment, etc. Chang-Ching Yang et al. [31] used anti-human specific nuclear antigen immunostaining to trace the survival and migration pattern of the hWJ-MSCs in the repair of rat spinal cord injury. Numerous hWJ-MSCs survived for at least four months after the transplantation according to the data obtained with the immunohistochemical analysis. In another study Forostyak et al. researched the survival and fate of the intrathecally delivered the human MSCs within CNS of the amyotrophic lateral sclerosis rats [31]. To determine the survival and the fate of the grafted cells, the spinal cord sec-

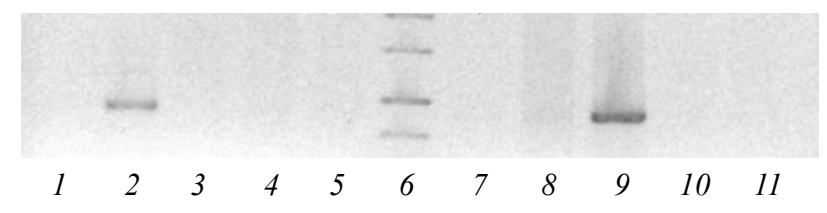

Fig. 4. The results of PCR for the presence of alpha-human DNA samples from rat cerebrum after administration of $\mathrm{hWJ}$ MSCs at different time intervals of post-transplantation. 1 - rat leukocyte DNA (negative control); 2 - 2 days; 3 - 2 days; 4 3 days; 5 - 3 days; 6 - molecular weight marker, $1 \mathrm{~kb}$ DNA Ladder (Fermentas); $7-4$ days; 8 - 4 days; $9-$ human MSC DNA (positive control); $10-5$ days; $11-5$ days

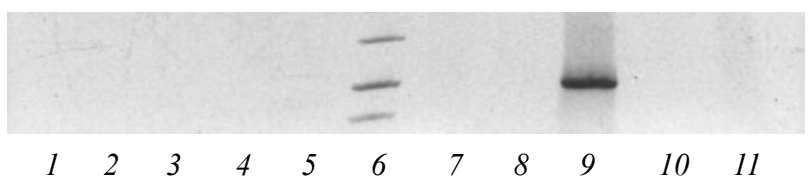

Fig. 5. The results of PCR for the presence of alpha-human DNA samples from spinal cord from lumbar region of rat spinal cord after administration of hWJ-MSCs at different time intervals of post-transplantation. 1 - rat leukocyte DNA (negative control); $2-2$ days; $3-2$ days; $4-3$ days; $5-3$ days; $6-$ molecular weight marker, $1 \mathrm{~kb}$ DNA Ladder (Fermentas); 7 4 days; $8-4$ days; 9 - human MSC DNA (positive control); $10-5$ days; $11-5$ days

tions were stained with the human-specific markers for mitochondria $(\mathrm{MtC02})$ and nuclei $(\mathrm{HuNu})$. It was shown that despite adequate immunosuppression, the transplanted MSCs did not survive in the CNS or subdural space of the affected rats at the $14^{\text {th }}$ day of post transplantation though the cells ameliorated the disease progression. In parallel experiment, in which the same number of rat $\mathrm{MSCs}^{\mathrm{GFP}+}$ was delivered into rats, already 14 days after the transplantation the GFP-positive cells could not be detected in the spinal cord and brain.

The literature data have shown that CSF also can influence the fate of the transplanted cells. Farivar et al. studied the effect of human CSF on the neural differentiation of hWJ-MSCs in vitro. It was shown by an expression analysis for the known neural markers (Nestin, GFAP, and MAP2) that CSF induced the neurogenesis of hWJ-MSCs [32]. However, there are also arguments that the CSF composition under the pathological conditions and exogenous environment limit the survival of the transplanted MSCs [31]. To date, the mechanisms 
underlying elimination of the transplanted MSCs by a host also require more thorough researches. In this context, the present study revealed that the intrathecally delivered hWJ-MSCs in the EAE rats were distributed across the affected CNS, overcame a transplantational shock and persisted during the initial days following transplantation. Assuming that according to the "hit-run mechanism" hypothesis, the long-term survival of the MSCs is not critical for their therapeutic activity, the cells can be used to deliver several therapeutic agents (growth factors, cytokines, etc.) into CNS. To determine how long hWJ-MSCs could persist in the CNS under the EAE pathological conditions, the additional long-term studies are needed.

\section{Conclusions}

The data obtained suggest that the intrathecally delivered hWJ-MSCs, with time, can migrate through the CSF from the injection site to various segments of CNS and persist therein during the first week post transplantation, which was performed at the EAE disease peak in the xenogeneic setting without immunosuppression. hWJ-MSCs may be considered as the delivery cell source of the therapeutic molecules for the cure of the CNS inflammatory diseases.

\section{REFERENCES}

1. Darlington PJ, Boivin MN, Bar-Or A. Harnessing the therapeutic potential of mesenchymal stem cells in multiple sclerosis. Expert Rev Neurother. 2011;11(9):1295-303.

2. Høglund RA, Maghazachi AA. Multiple sclerosis and the role of immune cells. World J Exp Med. 2014;4(3):27-37.

3. Mastorodemos V, Ioannou $M$, Verginis P. Cell-based modulation of autoimmune responses in multiple sclerosis and experimental autoimmmune encephalomyelitis: therapeutic implications. Neuroimmunomodulation. 2015;22(3):18195.

4. Goldenberg MM. Multiple sclerosis review. $P \quad T$. 2012;37(3):175-84.

5. Karussis D, Karageorgiou C, Vaknin-Dembinsky A, Gowda-Kurkalli B, Gomori JM, Kassis I, Bulte JW, Petrou P, Ben-Hur T, Abramsky O, Slavin S. Safety and immunological effects of mesenchymal stem cell transplantation in patients with multiple sclerosis and amyotrophic lateral sclerosis. Arch Neurol. 2010;67(10):1187-94.
6. Cohen JA. Mesenchymal stem cell transplantation in multiple sclerosis. J Neurol Sci. 2013;333(1-2):43-9.

7. Constantin $G$, Marconi $S$, Rossi B, Angiari $S$, Calderan L, Anghileri E, Gini B, Bach SD, Martinello M, Bifari F, Galiè $M$, Turano E, Budui S, Sbarbati A, Krampera M, Bonetti B. Adipose-derived mesenchymal stem cells ameliorate chronic experimental autoimmune encephalomyelitis. Stem Cells. 2009;27(10):2624-35.

8. Axelsson M, Malmeström C, Gunnarsson M, Zetterberg $H$, Sundström P, Lycke J, Svenningsson A. Immunosuppressive therapy reduces axonal damage in progressive multiple sclerosis. Mult Scler. 2014;20(1):43-50.

9. Lublin FD, Bowen JD, Huddlestone J, Kremenchutzky M, Carpenter A, Corboy JR, Freedman MS, Krupp L, Paulo C, Hariri RJ, Fischkoff $S A$. Human placenta-derived cells (PDA-001) for the treatment of adults with multiple sclerosis: a randomized, placebo-controlled, multiple-dose study. Mult Scler Relat Disord. 2014;3(6):696-704.

10. Maltman DJ, Hardy SA, Przyborski SA. Role of mesenchymal stem cells in neurogenesis and nervous system repair. Neurochem Int. 2011;59(3):347-56.

11. Uccelli A, Laroni A, Freedman MS. Mesenchymal stem cells for the treatment of multiple sclerosis and other neurological diseases. Lancet Neurol. 2011;10(7):649-56.

12. Keating $A$. Mesenchymal stromal cells: new directions. Cell Stem Cell. 2012;10(6):709-16.

13. Nakano N, Nakai Y, Seo TB, Homma T, Yamada Y, Ohta M, Suzuki Y, Nakatani T, Fukushima M, Hayashibe M, Ide C. Effects of bone marrow stromal cell transplantation through CSF on the subacute and chronic spinal cord injury in rats. PLoS One. 2013;8(9):e73494.

14. Isakova IA, Baker K, DuTreil M, Dufour J, Gaupp D, Phinney $D G$. Age- and dose-related effects on MSC engraftment levels and anatomical distribution in the central nervous systems of nonhuman primates: identification of novel MSC subpopulations that respond to guidance cues in brain. Stem Cells. 2007;25(12):3261-70.

15. Phinney DG, Baddoo M, Dutreil M, Gaupp D, Lai WT, Isakova IA. Murine mesenchymal stem cells transplanted to the central nervous system of neonatal versus adult mice exhibit distinct engraftment kinetics and express receptors that guide neuronal cell migration. Stem Cells Dev. 2006;15(3):437-47.

16. Zhou C, Yang B, Tian Y, Jiao H, Zheng W, Wang J, Guan F. Immunomodulatory effect of human umbilical cord Wharton's jelly-derived mesenchymal stem cells on lymphocytes. Cell Immunol. 2011;272(1):33-8.

17. Zhao G, Liu F, Lan S, Li P, Wang L, Kou J, Qi X, Fan R, Hao D, Wu C, Bai T, Li Y, Liu JY. Large-scale expansion of Wharton's jelly-derived mesenchymal stem cells on gelatin microbeads, with retention of self-renewal and multipotency characteristics and the capacity for enhancing skin wound healing. Stem Cell Res Ther. 2015;6:38. 
Distribution of transplanted human mesenchymal stem cells from Wharton's Jelly in the central nervous systems of the EAE rats

18. Romo-González T, Chavarría A, Pérez-HJ. Central nervous system: a modified immune surveillance circuit? Brain Behav Immun. 2012;26(6):823-9.

19. Law of Ukraine "The protection of animals from cruel behavior” from 21.02.2006 №3447-IV. Vidomosti of Verkhovna Rada of Ukraine. 2006; 27:990.

20. Guide for the Care and Use of laboratory Animals. Washington: National Academy Press, 1996. $136 \mathrm{p}$.

21. Maslova OO, Shuvalova NS, Sukhorada OM, Zhukova SM, Deryabina OG, Makarenko MV, Govseiev DO, Kordium VA. Heterogeneity of Umbilical Cords as a source for MSC. Dataset Pap Biol. 2013, 2013;370103

22. Dominici M, Le Blanc K, Mueller I, Slaper-Cortenbach I, Marini F, Krause D, Deans $R$, Keating A, Prockop Dj, Horwitz $E$. Minimal criteria for defining multipotent mesenchymal stromal cells. The International Society for Cellular Therapy position statement. Cytotherapy. 2006;8(4):315-7.

23. Feurer C, Prentice DE, Cammisuli S. Chronic relapsing experimental allergic encephalomyelitis in the Lewis rat. J Neuroimmunol. 1985;10(2):159-66.

24. Miller SD, Karpus WJ, Davidson TS. Experimental autoimmune encephalomyelitis in the mouse. Curr Protoc Immunol. 2007; Chapter: Unit-15.1.

25. Grimberg J, Nawoschik S, Belluscio L, McKee R, Turck A, Eisenberg $A$. A simple and efficient non-organic procedure for the isolation of genomic DNA from blood. Nucleic Acids Res. 1989;17(20):8390.

26. Biase FH, Franco MM, Goulart LR, Antunes RC. Protocol for extraction of genomic DNA from swine solid tissues. Genet Mol Biol.2002;25(3):313-5.

27. Becker M, Nitsche A, Neumann C, Aumann J, Junghahn I, Fichtner I. Sensitive PCR method for the detection and realtime quantification of human cells in xenotransplantation systems. Br J Cancer. 2002;87(11):1328-35.

28. Warburton PE, Greig GM, Haaf T, Willard HF. PCR amplification of chromosome-specific alpha satellite DNA: definition of centromeric STS markers and polymorphic analysis. Genomics. 1991;11(2):324-33.

29. Kovalchuk MV, Shuvalova NS, Pokholenko IO, Dragulyan MV, Gulko TP, Deryabina OG, Kordium VA. Monitoring of transplanted human Mesenchymal Stem Cells from Wharton's Jelly in xenogeneic systems in vivo. Biopolym Cell. 2015;31(3):193-9.

30. Agrawal H, Shang H, Sattah AP, Yang N, Peirce SM, Katz $A J$. Human adipose-derived stromal/stem cells demonstrate short-lived persistence after implantation in both an immunocompetent and an immunocompromised murine model. Stem Cell Res Ther. 2014;5(6):142.

31. Forostyak S, Homola A, Turnovcova K, Svitil P, Jendelova $P$, Sykova E. Intrathecal delivery of mesenchymal stromal cells protects the structure of altered perineuronal nets in SOD1 rats and amends the course of ALS. Stem Cells. 2014;32(12):3163-72.
32. Farivar S, Mohamadzade Z, Shiari R, Fahimzad A. Neural differentiation of human umbilical cord mesenchymal stem cells by cerebrospinal fluid. Iran $J$ Child Neurol. 2015;9(1):87-93.

\section{Розподіл трансплантованих МСК Вартонового студня пуповини людини в центральній нервовій системі щурів 3 експериментальним аутоімунним енцефаломіслом}

М. В. Ковальчук, О. Г. Дерябіна, Л. Д. Пічкур, С. А. Вербовська, Н. С. Шувалова, О. Л. Пічкур, В. А. Кордюм

Мезенхімальні стовбурові клітини Вартонового студня пуповини людини (МСК-ВС) мають значну перевагу і потенціал у лікуванні захворювань центральної нервової системи (ЦНС) і можуть стати новою альтернативною терапією для розсіяного склерозу (РС). Мета. Вивчити виживання і розподіл МСК-ВС в ЦНС щурів з ЕАЕ після субокціпітальної трансплантації. Методи. Виділення і культивування МСК-ВС in vitro. Імунологічне фенотипування методом проточної цитофлюориметрії. Індукція ЕАЕ. Інтратекальне введення МСК в ЦНС щурів лінії Wistar з EAE, індукованим гомогенатом спинного мозку (ГСМ). Виживання МСК-ВС в ЦНС щурів оцінювали за допомогою виявлення людської альфа-сателітної ДНК у зразках тканин та спинномозковій рідині (CMP) на 2, 3, 4, та 5 дні за допомогою ПЛР. Результати. ПЛР-аналіз для альфа-сателітних послідовностей показав, що ДНК людини виявлялася протягом 5 днів після інтратекального введення, на піку симптомів. Було показано, що трансплантовані ксеногенні МСК-ВС мігрували через СМР в різні сегменти спинного мозку. Висновки. Отримані результати дозволяють припустити, що МСК-ВС, введені інтратекально, можуть мігрувати зі струмом СМР в різні відділи ЦНС і перебувати в них протягом першого тижня після трансплантації на піку захворювання ЕАЕ в ксеногенному варіанті без імуносупресії. МСК-ВС можна розглядати як джерело клітин для доставки терапевтичних молекул для лікування запальних захворювань ЦНС.

Кл юч о в і с л о в а: МСК-ВС, експериментальний аутоімунний енцефаломієліт, альфа-сателітна ДНК.

Распределение трансплантированных МСК Вартонового студня пуповины человека в центральной нервной системе крыс с экспериментальным аутоиммунным энцефаломиелитом

М. В. Ковальчук, Е. Г. Дерябина, Л. Д. Пичкур,

С. А. Вербовская, Н. С. Шувалова, А. Л. Пичкур,

В. А. Кордюм

Мезенхимальные стволовые клетки Вартонового студня пуповины человека (МСК-ВС) имеют значительное преимущество перед другими видами стволовых клеток и потенциал в лечении заболеваний центральной нервной системы (ЦНС) и мо- 
гут стать новой альтернативной терапией для рассеянного склероза. Цель. Изучить выживание и распределение МСКВС в ЦНС крыс с ЭАЭ после субоксипитальной трансплантации. Методы. Выделение и культивирование МСК-BC in vitro. Иммунологическое фенотипирование методом проточной цитофлюориметрии. Индукция ЭАЭ. Интратекальное (субокципитальное) введение МСК в ЦНС крыс линии Wistar с ЭАЭ, индуцированным гомогенатом спинного мозга (ГСМ). Выживание МСК-ВС в ЦНС крыс оценивали с помощью выявления человеческой альфа-сателлитной ДНК в образцах тканей и спинномозговой жидкости (СМЖ) на 2, 3, 4 и 5 дни с помощью ПЦР. Результаты. ПЦР-анализ для альфа-сателлитных последовательностей показал, что ДНК человека обнаруживалась в течение 5 дней после интратекального введения, на пике симптомов. Было показано, что трансплантированные ксеногенные МСК-ВС мигрировали через спинномозговую жидкость (СМЖ) в различные сегменты спинного мозга. Выводы. Полученные результаты позволяют предположить, что МСК-ВС, введенные интратекально, со временем,могут мигрировать с током СМЖ в различные отделы ЦНС и находиться в них на протяжении первой недели после трансплантации на пике заболевания ЭАЭ в ксеногенном варианте без иммуносупрессии. МСК-ВС можно рассматривать как источник клеток для доставки терапевтических молекул для лечения воспалительных заболеваний ЦНС.

Кл юче в ы е сл о в а: МСК-ВС, экспериментальный аутоиммунный энцефаломиелит, альфа-сателлитная ДНК.

Received 02.06.2015 